\title{
Influence of Synthesis Gas Components on Hydrogen Storage Properties of Sodium Aluminum Hexahydride
}

\author{
Tai Sun ${ }^{1}$, Kateryna Peinecke ${ }^{2}$, Robert Urbanczyk ${ }^{3}$ and Michael Felderhoff ${ }^{2, *}$ \\ 1 Guangdong Key Laboratory of Rare Earth Development and Application, Guangdong Research Institute of \\ Rare Metals, Guangzhou 510650, China; oksuntai@126.com \\ 2 Department of Heterogeneous Catalysis, Max-Planck-Institut für Kohlenforschung, Kaiser-Wilhelm-Platz 1, \\ 45470 Mülheim an der Ruhr, Germany; peinecke@mpi-muelheim.mpg.de \\ 3 Department of Energie \& Ressourcen, Institut für Energie- und Umwelttechnik e.V., Bliersheimer Str. 58-60, \\ 47229 Duisburg, Germany; urbanczyk@iuta.de \\ * Correspondence: felderhoff@mpi-muelheim.mpg.de; Tel.: +49-(0)208-306-2450
}

check for

updates

Citation: Sun, T.; Peinecke, K.; Urbanczyk, R.; Felderhoff, M. Influence of Synthesis Gas Components on Hydrogen Storage Properties of Sodium Aluminum Hexahydride. Hydrogen 2021, 2 , 147-159. https://doi.org/10.3390/ hydrogen2010009

Academic Editor: George

E. Marnellos

Received: 23 December 2020

Accepted: 22 February 2021

Published: 26 February 2021

Publisher's Note: MDPI stays neutral with regard to jurisdictional claims in published maps and institutional affiliations.

Copyright: (C) 2021 by the authors Licensee MDPI, Basel, Switzerland. This article is an open access article distributed under the terms and conditions of the Creative Commons Attribution (CC BY) license (https:/ / creativecommons.org/licenses/by/ $4.0 /)$.

\begin{abstract}
A systematic study of different ratios of $\mathrm{CO}, \mathrm{CO}_{2}, \mathrm{~N}_{2}$ gas components on the hydrogen storage properties of the $\mathrm{Na}_{3} \mathrm{AlH}_{6}$ complex hydride with $4 \mathrm{~mol} \% \mathrm{TiCl}_{3}, 8 \mathrm{~mol} \%$ aluminum and 8 $\mathrm{mol} \%$ activated carbon is presented in this paper. The different concentrations of $\mathrm{CO}$ and $\mathrm{CO}_{2}$ in $\mathrm{H}_{2}$ and $\mathrm{CO}, \mathrm{CO}_{2}, \mathrm{~N}_{2}$ in $\mathrm{H}_{2}$ mixture were investigated. Both $\mathrm{CO}$ and $\mathrm{CO}_{2}$ gas react with the complex hydride forming $\mathrm{Al}$ oxy-compounds, $\mathrm{NaOH}$ and $\mathrm{Na}_{2} \mathrm{CO}_{3}$ that consequently cause serious decline in hydrogen storage capacity. These reactions lead to irreversible damage of complex hydride under the current experimental condition. Thus, after 10 cycles with $0.1 \mathrm{vol} \% \mathrm{CO}+99.9 \mathrm{vol} \% \mathrm{H}_{2}$ and 1 vol $\% \mathrm{CO}+99 \mathrm{vol} \% \mathrm{H}_{2}$, the dehydrogenation storage capacity of the composite material decreased by $17.2 \%$ and $57.3 \%$, respectively. In the case of investigation of 10 cycles with $1 \mathrm{vol} \% \mathrm{CO}_{2}+99 \mathrm{vol} \%$ $\mathrm{H}_{2}$ gas mixture, the capacity degradation was $53.5 \%$. After 2 cycles with $10 \mathrm{vol} \% \mathrm{CO}+90 \mathrm{vol} \% \mathrm{H}_{2}$, full degradation was observed, whereas after 6 cycles with $10 \mathrm{vol} \% \mathrm{CO}_{2}+90 \mathrm{vol} \% \mathrm{H}_{2}$, degradation of $86.8 \%$ was measured. While testing with the gas mixture of $1.5 \mathrm{vol} \% \mathrm{CO}+10 \mathrm{vol} \% \mathrm{CO}_{2}+27 \mathrm{vol}$ $\% \mathrm{H}_{2}+61.5 \mathrm{vol} \% \mathrm{~N}_{2}$, the degradation of $94 \%$ after 6 cycles was shown. According to these results, it must be concluded that complex aluminum hydrides cannot be used for the absorption of hydrogen from syngas mixtures without thorough purification.
\end{abstract}

Keywords: hydrogen storage; $\mathrm{Na}_{3} \mathrm{AlH}_{6}$; complex hydride; hydrogen impurity

\section{Introduction}

Hydrogen storage is a key enabling technology for bringing forward hydrogen and fuel cell technologies in applications including transportation, stationary and portable power. For these applications, the volumetric and gravimetric hydrogen storage capacities are essential. Hydrogen can be physically stored as a gas under high pressure (35-70 $\mathrm{MPa}$ in high-pressure tanks) or as a liquid at cryogenic temperatures, since hydrogen boils at $20 \mathrm{~K}$ at ambient pressure. Besides, hydrogen can be stored in materials by adsorption (in the high surface solids, e.g., carbon materials or metal organic frameworks (MOFs) at temperatures $<77 \mathrm{~K}$ ) or absorption (within solids, e.g., metal hydrides, complex metal hydrides, and alloys). In comparison to other methods, storage of absorbed hydrogen within metal hydrides or complex metal hydrides can offer high volumetric storage capacity up to $150 \mathrm{~kg} \mathrm{~m}^{-3}[1,2]$.

Sodium aluminum hexahydride- $\mathrm{Na}_{3} \mathrm{AlH}_{6}$ with Ti catalysts was tested in our prior research as a storage material for the use in a lightweight aluminum alloy storage tank [3]. It was shown that the storage material could practically absorb/release up to $2.0 \mathrm{wt} \%$ of hydrogen during the hydrogenation/dehydrogenation processes. Although the material exhibits stable behavior of the kinetics performance, the capacity and the cyclic stability of the material still needs further optimization for commercial applications. Hydrogen which 
can be used for recharging metal hydrides is a constituent of synthesis gas that is usually generated by the endothermic steam reforming of hydrocarbons, partial oxidation of methane, or gasification of coal and biomass $[4,5]$. The majority of hydrogen is produced by steam reforming of natural gas that is reacting with steam in the presence of Ni catalyst [6] as follows (Equation (1)):

$$
\mathrm{CH}_{4}+\mathrm{H}_{2} \mathrm{O} \rightleftharpoons 3 \mathrm{H}_{2}+\mathrm{CO}\left(\Delta \mathrm{H}_{\mathrm{R}}=206 \mathrm{~kJ} \mathrm{~mol}_{\mathrm{CH} 4}{ }^{-1}\right) \text {. }
$$

Partial oxidation of methane occurs when a sub-stoichiometric fuel-air mixture combusted forming a hydrogen-rich synthesis gas in an exothermic process according to Equation (2) [7]:

$$
\mathrm{CH}_{4}+0.5 \mathrm{O}_{2} \rightleftharpoons \mathrm{CO}+2 \mathrm{H}_{2}\left(\Delta \mathrm{H}_{\mathrm{R}}=-38 \mathrm{~kJ} \operatorname{mol}_{\mathrm{CH} 4}{ }^{-1}\right) \text {. }
$$

Autothermal reforming combines the steam reforming process and fuel oxidation in one unit. The energy for the endothermic steam reforming is provided by the exothermic oxidation resulting in an overall reaction enthalpy close to zero (Equation (3)) [8]:

$$
4 \mathrm{CH}_{4}+2 \mathrm{H}_{2} \mathrm{O}+\mathrm{O}_{2} \rightleftharpoons 10 \mathrm{H}_{2}+4 \mathrm{CO}\left(\Delta H_{\mathrm{R}}=0 \mathrm{~kJ} \mathrm{~mol}_{\mathrm{CH} 4}{ }^{-1}\right)
$$

During the above-mentioned synthesis gas processes, various gas compositions can be expected at the outlet of the appropriate reactor [9]. The resulting gas contents are shown in Table 1. The highest hydrogen content can be achieved during steam reforming and the lowest hydrogen content in the partial oxidation process.

Table 1. Synthesis gas compositions achievable in different reforming processes [9].

\begin{tabular}{cccccc}
\hline & $\mathbf{H}_{\mathbf{2}}$ [vol \%] & $\mathrm{CO}[\mathrm{vol} \%]$ & $\mathrm{CO}_{\mathbf{2}}[\mathrm{vol} \%]$ & $\mathrm{CH}_{\mathbf{4}}$ [vol \%] & $\mathbf{N}_{\mathbf{2}}$ [vol \%] \\
\hline $\begin{array}{c}\text { Steam } \\
\text { Reforming }\end{array}$ & $75-78$ & $8-10$ & $10-12$ & $2-5$ & 0 \\
$\begin{array}{c}\text { Autothermal } \\
\text { Reforming } \\
\text { Partial }\end{array}$ & $32-36$ & $9-11$ & $8-10$ & $0.2-4$ & $48-52$ \\
Oxidation & $24-34$ & $14-18$ & $0.6-2$ & 0 & $43-52$ \\
\hline
\end{tabular}

The synthesis gas components such as $\mathrm{CO}, \mathrm{CO}_{2}, \mathrm{CH}_{4}, \mathrm{~N}_{2}$, and $\mathrm{H}_{2} \mathrm{O}$ are suspected to be harmful for complex metal hydrides. Limited information could be found on the influence of these gas constituencies on complex metal hydrides. In 2007, Sandia National Laboratories published the results of reactivity of sodium alanate with $\mathrm{O}_{2}, \mathrm{H}_{2} \mathrm{O}$, and $\mathrm{CO}_{2}$. It was shown that sodium alanate reacts exothermically with $\mathrm{H}_{2} \mathrm{O}$ and $\mathrm{O}_{2}$ producing various $\mathrm{Na}-\mathrm{O}$ compounds and $\mathrm{H}_{2}$ [10]. The gas-solid reaction of $\mathrm{CO}_{2}$ with alanates was investigated by Hugelshofer et al. where the authors observed the formation of intermediates like aluminum formate and methoxy compounds which then got converted into methane and metal oxides as final products [11]. The influences of gas components on other metal hydrides are well investigated [12-24]. In this work, the influence of different ratios of $\mathrm{CO}, \mathrm{CO}_{2}, \mathrm{~N}_{2}$ on the hydrogen storage performance of the complex metal hydride $\mathrm{Na}_{3} \mathrm{AlH}_{6}$ with $4 \mathrm{~mol} \% \mathrm{TiCl}_{3}, 8 \mathrm{~mol} \%$ aluminum and $8 \mathrm{~mol} \%$ activated carbon is explored.

\section{Experimental Section}

The detailed description of the synthesis of $\mathrm{TiCl}_{3}$ - doped $\mathrm{Na}_{3} \mathrm{AlH}_{6}$ was reported in our previous publication [25]. $\mathrm{NaH}$ (60\% dispersion in mineral oil, Sigma-Aldrich, St. Louis, MO, USA) and $\mathrm{NaAlH}_{4}$ (95\% technical grade, Sigma-Aldrich) both after purification, aluminum powder (99\%, Sigma-Aldrich), activated carbon, and $\mathrm{TiCl}_{3}$ (Sigma-Aldrich) were used. The composite was prepared by mechano-chemical synthesis of 2:1 molar ratio of $\mathrm{NaH}$ and $\mathrm{NaAlH}_{4}, 4 \mathrm{~mol} \%$ of $\mathrm{TiCl}_{3}, 8 \mathrm{~mol} \%$ of aluminum, and $8 \mathrm{~mol} \%$ activated carbon 
under Argon inert atmosphere using hardened steel grinding bowls and balls in a Planetary Mill PULVERISETTE 5 (Fritsch GmbH, Idar-Oberstein, Germany).

Cycling tests of the composite were carried out in a fully automated Sieverts instrument PCTPro 2000 (SETARAM Inc., Caluire, France). Then, $2.0 \mathrm{~g}$ of material was used for each test. Hydrogenations were done at $2.5 \mathrm{MPa}$ hydrogen pressure at $170^{\circ} \mathrm{C}$ and dehydrogenations at $0.1 \mathrm{MPa}$ at $170{ }^{\circ} \mathrm{C}$. The XRD measurement was performed on the STOE STADI $\mathrm{P}(\mathrm{Cu}-\mathrm{K} \alpha$ radiation, $1.541 \AA)$ in a $0.5 \mathrm{~mm}$ diameter capillary filled with purified argon (both $\mathrm{H}_{2} \mathrm{O}$ and $\mathrm{O}_{2}<1 \mathrm{ppm}$ ). The IR-Spectrum measurements of the gaseous products were performed with a NICOLET MAGNA 560 FTIR spectrometer using Smart OMNITransmission cell with $\mathrm{KBr}$ windows. The gas sample was taken directly from the autoclave to the gas bag, being subsequently transferred into the Smart OMNI-Transmission cell. The gas phase spectra were taken at room temperature. Handling of the material was done in the MBraun glove box, in Argon atmosphere where oxygen and water levels always kept below 1 ppm.

The solid-state ${ }^{13} \mathrm{C}$ NMR spectra were recorded on a Bruker Avance III HD 500WB spectrometer using a double-bearing magic angle spinning (MAS) probe (DVT BL4) at a resonance frequency of $125.8 \mathrm{MHz}$. The experimental conditions for ${ }^{13} \mathrm{C} C \mathrm{CP}$ MAS NMR were as follows: $10-12 \mathrm{kHz}$ spinning rate, 3 s recycle delay, 20,000-52,000 scans, $2 \mathrm{~ms}$ contact time, $3.3 \mu \mathrm{s}{ }^{1} \mathrm{H} \pi / 2$ pulse, and high-power proton decoupling (spinal64). The ${ }^{13} \mathrm{C}$ chemical shift was referenced with respect to neat TMS in a separate rotor.

The hydrogenation and dehydrogenation cycles with gas mixtures were performed on a test rig shown in Figure 1. The autoclave was charged with a total pressure of 3.0 MPa of pure hydrogen or gas mixtures (Table 2) except of $11.0 \mathrm{MPa}$ for the gas mixture in 7 (Table 2). Gas mixture 7 was used as an example for autothermal syngas production from propane/butane mixtures of a commercial system. All gas mixtures were prepared in house. The autoclave was heated using a JUMO controller. The pressure inside the autoclave was monitored by JUMO pressure sensor and the temperature by a type $\mathrm{K}$ thermocouple. After the hydrogenation test, the hydrogen or gas mixture overpressure was released through the overpressure release valve. Immediately after releasing the gas pressure, desorbed hydrogen was collected and measured using a calibrated gas burette.

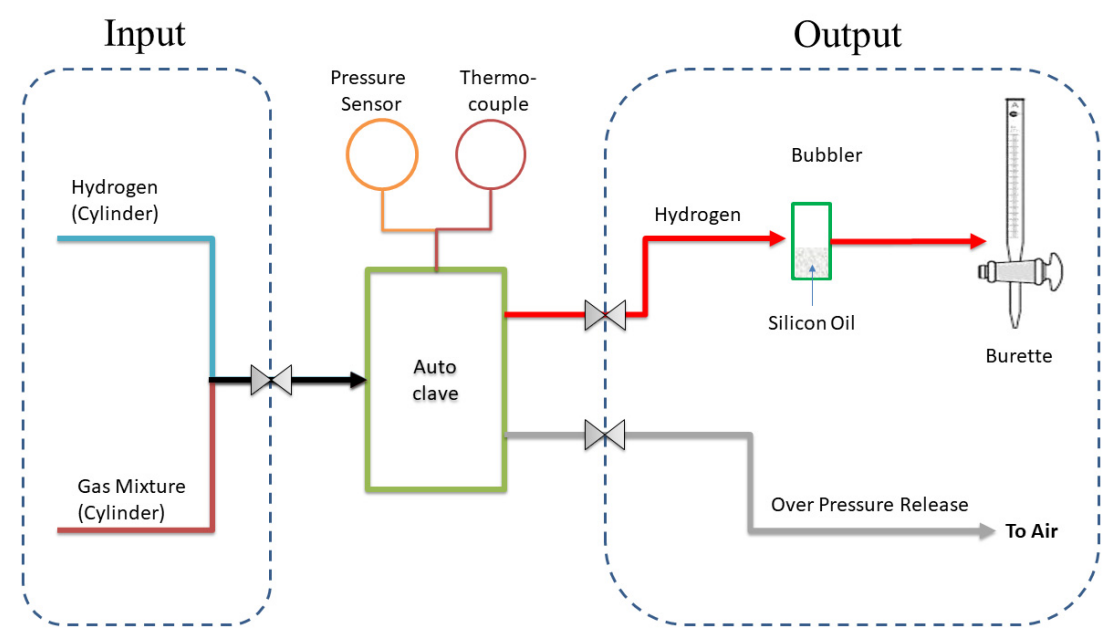

Figure 1. Sketch of the hydrogenation/dehydrogenation set-up. 
Table 2. Tested gas mixtures.

\begin{tabular}{cccccc}
\hline & $\begin{array}{c}\mathbf{H}_{\mathbf{2}} \\
{[\mathbf{v o l} \%]}\end{array}$ & $\begin{array}{c}\mathrm{CO} \\
{[\mathbf{v o l} \%]}\end{array}$ & $\begin{array}{c}\mathrm{CO}_{2} \\
{[\mathbf{v o l} \%]}\end{array}$ & $\begin{array}{c}\mathrm{CH}_{4} \\
{[\mathbf{v o l} \%]}\end{array}$ & $\begin{array}{c}\mathbf{N}_{\mathbf{2}} \\
\text { [vol \%] }\end{array}$ \\
\hline 1 & 99.9 & 0.1 & & & \\
2 & 99 & 1 & & & \\
3 & 90 & 10 & 1 & & \\
4 & 99 & & 10 & & 62 \\
5 & 90 & & & 0 & 61.5 \\
6 & 38 & 1.5 & 10 & & \\
7 & 27 & &
\end{tabular}

\section{Results}

\subsection{Hydrogen Storage Performance of the $\mathrm{Na}_{3} \mathrm{AlH}_{6}$ Composite Material in Pure Hydrogen}

Activated carbon $(8 \mathrm{~mol} \%)$ and aluminum $(8 \mathrm{~mol} \%)$ were added to $\mathrm{Na}_{3} \mathrm{AlH}_{6}$ and $\mathrm{TiCl}_{3}(4 \mathrm{~mol} \%)$ to enhance heat transfer of the composite material, which could improve the hydrogenation and dehydrogenation kinetic as well as dispersion, which can prevent the material from sintering during long time cycling. The other reason for addition of aluminum is that the forming of Ti-Al alloy during doping processes would consume part of $\mathrm{Al}$ from $\mathrm{Na}_{3} \mathrm{AlH}_{6}$. To replace this consumed $\mathrm{Al}$ metal and as the result to maintain the reversibility of the system, the amount of $8 \mathrm{~mol} \% \mathrm{Al}$ is added [25].

Here, we define that one "cycle" includes one hydrogenation and one dehydrogenation process. A complete cycle takes $4 \mathrm{~h}$, including $2 \mathrm{~h}$ of hydrogenation and $2 \mathrm{~h}$ of dehydrogenation. As shown in Figure 2, 187 cycles were achieved without notable degradation. Every hydrogenation cycle was performed at $2.5 \mathrm{MPa}$ hydrogen pressure and 170 ${ }^{\circ} \mathrm{C}$, while every dehydrogenation cycle was performed at $0.1 \mathrm{MPa}$ pressure and $170{ }^{\circ} \mathrm{C}$. Then, $2.15 \pm 0.02 \mathrm{wt} \%$ of hydrogen was evolved and absorbed during hydrogenation or dehydrogenation. This value will be used as hydrogen normalized capacity in cycling experiments. In our prior research, the hydrogen capacity of the composite without additives of $\mathrm{Al}$ and activated carbon was less than $1.7 \mathrm{wt} \%$ [26]. Addition of activated carbon and $\mathrm{Al}$ has improved stability and hydrogen storage capacity of the composite by more than $30 \%$ and therefore confirmed the benefits of these additives. In general, the addition of carbon materials to metal hydride compounds results in improved kinetics of dehydrogenation and hydrogenation and the ability to transport and to release the produced heat during the reaction with hydrogen [27].

Table 3 shows the dehydrogenation $\mathrm{H}_{2}$ capacity ( $0.1 \mathrm{MPa}$ dehydrogenation pressure) of samples hydrogenated for $0.5,1$, and $2 \mathrm{~h}$. The dehydrogenation time was varied between 1,2 , and $3 \mathrm{~h}$. The hydrogenation and dehydrogenation temperatures were changed between 180 and $150{ }^{\circ} \mathrm{C}$. It can be observed, that when temperature is higher than or equal to 160 ${ }^{\circ} \mathrm{C}$, only $1 \mathrm{~h}$ is needed to fully hydrogenate the material at 3.0 $\mathrm{MPa}$ or dehydrogenate the material at $0.1 \mathrm{MPa}$. Increasing hydrogenation or dehydrogenation time to 2 or $3 \mathrm{~h}$ does not improve or only slightly improves the hydrogen capacity. At $150{ }^{\circ} \mathrm{C}$, extending of hydrogenation and dehydrogenation time is necessary to obtain higher $\mathrm{H}_{2}$ capacity. As result of these investigations, it was concluded to perform the cycling experiments with synthesis gas components at $170{ }^{\circ} \mathrm{C}$ and use $1 \mathrm{~h}$ for hydrogenation and $1 \mathrm{~h}$ for dehydrogenation processes. 


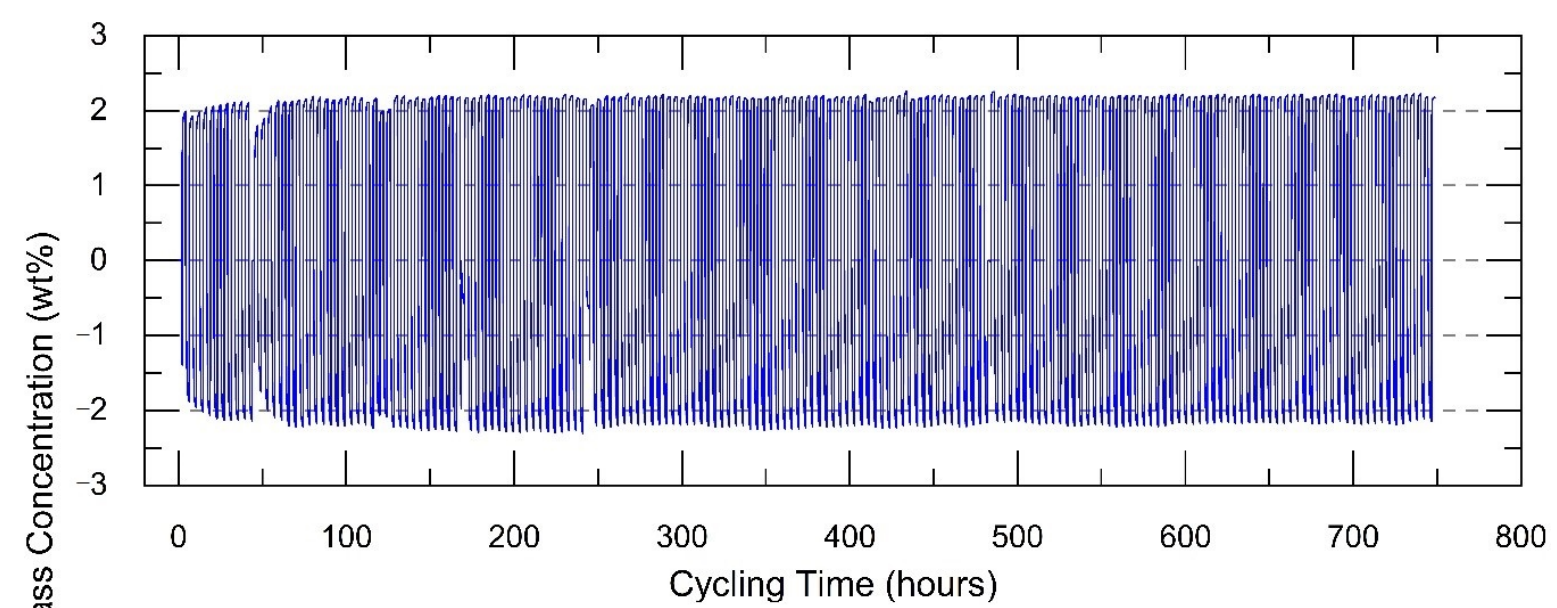

(a)

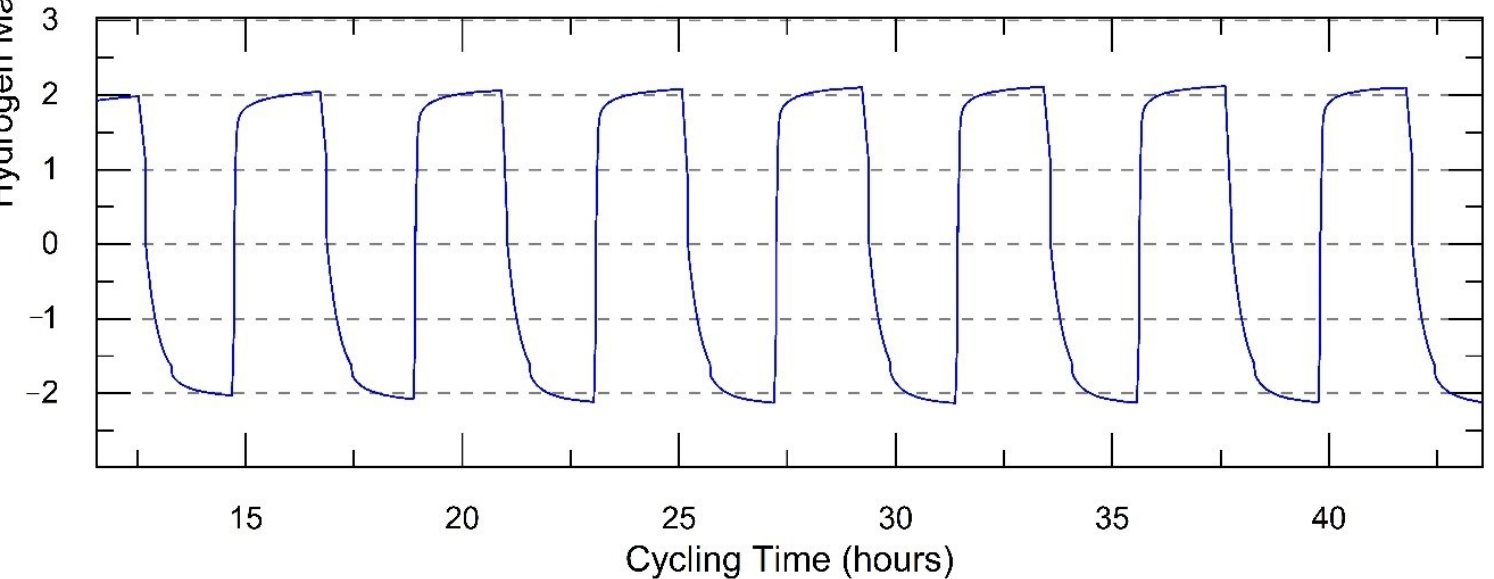

(b)

Figure 2. Cycling performance of $\mathrm{Na}_{3} \mathrm{AlH}_{6}+\mathrm{TiCl}_{3}+\mathrm{Al}+\mathrm{AC}$ composite: hydrogenation at $2.5 \mathrm{MPa}$ and $170{ }^{\circ} \mathrm{C}$, dehydrogenation at $0.1 \mathrm{MPa}$ and $170{ }^{\circ} \mathrm{C}$ : (a) total cycling hours; (b) detailed view of 7 cycle s (11-46 cycling hours).

Table 3. $\mathrm{H}_{2}$ capacity of the $\mathrm{Na}_{3} \mathrm{AlH}_{6}$ composite at different temperature and time during dehydrogenation at $0.1 \mathrm{MPa}$.

\begin{tabular}{ccccc}
\hline \multirow{2}{*}{$\begin{array}{c}\text { Temperature } \\
{\left[{ }^{\circ} \mathbf{C}\right]}\end{array}$} & $\begin{array}{c}\text { Hydrogenation Time } \\
{[\mathbf{h}]}\end{array}$ & \multicolumn{3}{c}{ Dehydrogenation $\mathbf{H}_{\mathbf{2}}$ Capacity [wt \%] } \\
\cline { 3 - 5 } & 0.5 & $\mathbf{1} \mathbf{h}$ & $\mathbf{2} \mathbf{~ h}$ & $\mathbf{3} \mathbf{~ h}$ \\
\hline \multirow{3}{*}{180} & 1 & 2.2 & 2.2 & $\mathrm{~N} / \mathrm{A}$ \\
& 2 & 2.2 & 2.2 & $\mathrm{~N} / \mathrm{A}$ \\
& 0.5 & 2.2 & 2.2 & 2.2 \\
\hline \multirow{2}{*}{170} & 1 & 2.0 & 2.1 & $\mathrm{~N} / \mathrm{A}$ \\
& 2 & 2.2 & 2.3 & 2.4 \\
& 0.5 & 2.2 & 2.3 & 2.4 \\
\hline \multirow{2}{*}{160} & 1 & 2.0 & 2.1 & 2.2 \\
& 2 & 2.0 & 2.1 & 2.1 \\
& 0.5 & 2.0 & 2.1 & 2.1 \\
\hline & 1 & 1.7 & 2.0 & 2.1 \\
& 2 & 1.7 & 2.1 & 2.3 \\
& & 1.7 & 2.1 & 2.3 \\
\hline
\end{tabular}

3.2. The Influence of $\mathrm{CO}$ Gas on the Cycling Behavior of the Ti-Doped $\mathrm{Na}_{3} \mathrm{AlH}_{6}$

Figure 3 shows the hydrogen storage performance of the composite material in different ratios of $\mathrm{CO}$ and $\mathrm{H}_{2}$ gas mixture. After 10 cycles with $0.1 \mathrm{vol} \% \mathrm{CO}+99.9 \mathrm{vol} \% \mathrm{H}_{2}$ and $1 \mathrm{vol} \% \mathrm{CO}+99 \mathrm{vol} \% \mathrm{H}_{2}$, the dehydrogenation storage capacity of the composite material decreased by $17.2 \%$ and $57.3 \%$, respectively. The sample cycled with $10 \mathrm{vol} \%$ 
$\mathrm{CO}+90 \mathrm{vol} \% \mathrm{H}_{2}$ gas mixture shows the most severe degradation. There was almost no hydrogen released after only 2 cycles after hydrogenation with $10 \mathrm{vol} \% \mathrm{CO}+90 \mathrm{vol} \% \mathrm{H}_{2}$ gas mixture. Attempts to recharge the sample with $5 \mathrm{MPa}$ of pure hydrogen failed, which means that the changes during the cycling with the gas contained $10 \mathrm{vol} \% \mathrm{CO}$ seem to be irreversible. Figure 4 shows the $\mathrm{X}$-ray diffraction pattern of the doped $\mathrm{Na}_{3} \mathrm{AH}_{6}$ material after treatment with different amounts of $\mathrm{CO}$ in $\mathrm{H}_{2}$. It can be seen that $\mathrm{Na}$ oxides were formed after 10 cycles with $0.1 \mathrm{vol} \% \mathrm{CO}+99.9 \mathrm{vol} \% \mathrm{H}_{2}$ and $1 \mathrm{vol} \% \mathrm{CO}+99 \mathrm{vol} \% \mathrm{H}_{2}$. In case of $10 \mathrm{vol} \% \mathrm{CO}+90 \mathrm{vol} \% \mathrm{H}_{2}$ mixture, the formation of $\mathrm{NaOH}$ can be observed just after 2 cycles. The peak intensity ratio of $\mathrm{Al}: \mathrm{NaCl}$ at around $45^{\circ}(2 \theta)$ becomes smaller when the concentration of $\mathrm{CO}$ increases in the gas mixture. The $\mathrm{Al}$ peak with $10 \mathrm{vol} \% \mathrm{CO}+90$ vol $\% \mathrm{H}_{2}$ sample almost disappears after 2 cycles. As shown in the embedded enlarged Figure 4 , a new weak reflection at round $37.4^{\circ}(2 \theta)$ appeared. This peak may belong to some kind of $\mathrm{Al}$ oxygenates.

In order to get more information about the weak reflection at round $37.4^{\circ}(2 \theta)$ observed in the X-ray diffraction pattern of Figure 4, we measured a carbon solid state NMRspectrum. Figure 5 shows the ${ }^{13} \mathrm{C} C \mathrm{CP} / \mathrm{MAS}$ NMR spectrum of Ti-doped $\mathrm{Na}_{3} \mathrm{AlH}_{6}$ after the second hydrogenation with $10 \mathrm{vol} \% \mathrm{CO}+90 \mathrm{vol} \% \mathrm{H}_{2}$ gas mixture. The most intense and asymmetric line at about $51 \mathrm{ppm}$ in the ${ }^{13} \mathrm{C}$ NMR spectrum in Figure 5 can be assigned to methoxy groups $\left(\mathrm{O}-\mathrm{CH}_{3}\right)$ [28]. These methoxy groups can be connected to Al- and/or Naatoms. The observation of $\mathrm{O}-\mathrm{CH}_{3}$-groups also confirms the detection of $\mathrm{Al}-\mathrm{O}$-compounds in the X-ray diffraction pattern in Figure 4. The high-field line at about $-8 \mathrm{ppm}$ stems most likely from methyl groups directly bound to aluminum atoms [29]. The spectral intensity between 10 and $40 \mathrm{ppm}$ is partly due to a small background signal of the probe.

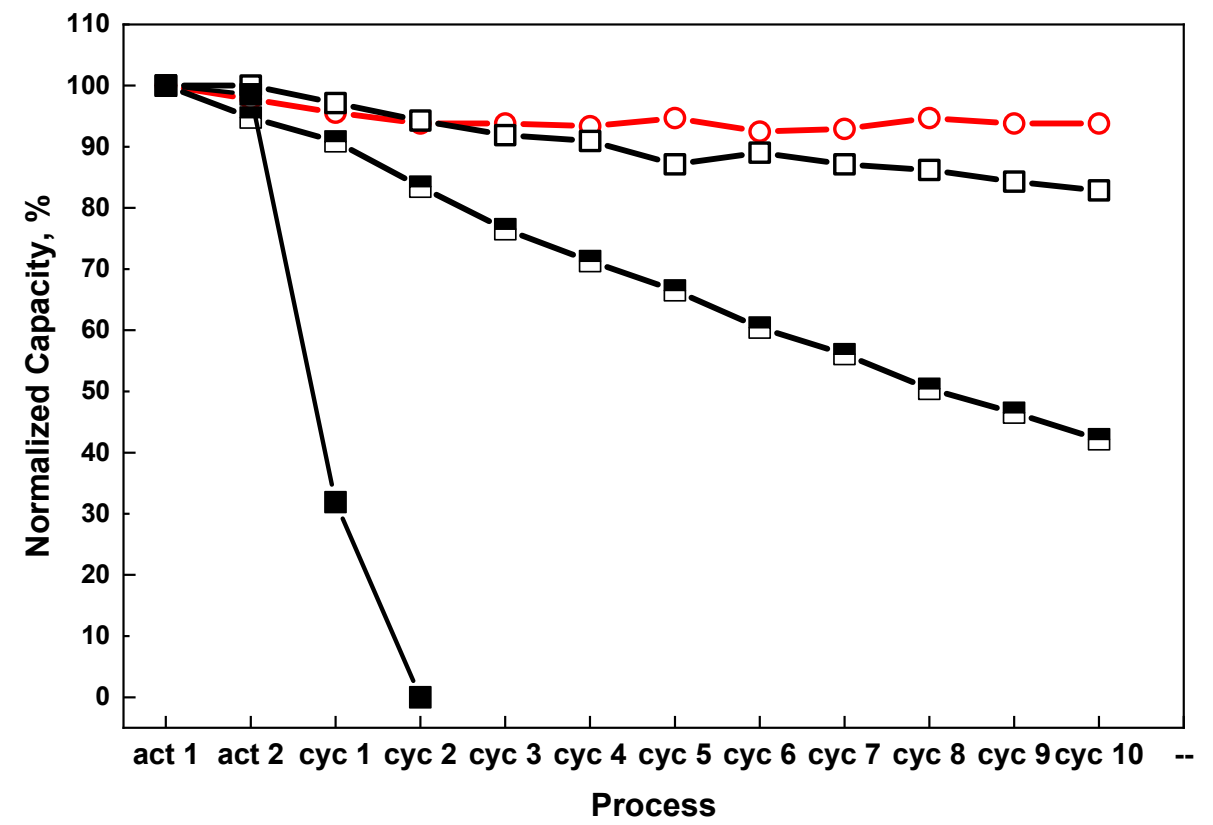

Figure 3. Cyclic performance of the composite material at $170{ }^{\circ} \mathrm{C}$ under $3.0 \mathrm{MPa}$ with different $\mathrm{CO}+$ $\mathrm{H}_{2}$ ratios. All samples were hydrogenated and dehydrogenated in pure hydrogen twice ("activation 1 (act 1 ) and activation 2 (act 2)) before cycling in the gas mixture. $-\mathrm{O}-\mathrm{Pure}_{2},-\square-0.1$ vol \% $\mathrm{CO}+99.9$ vol \% $\mathrm{H}_{2},-\mathbf{-}-1 \mathrm{vol} \% \mathrm{CO}+99 \mathrm{vol} \% \mathrm{H}_{2},-\mathbf{-}-10 \mathrm{vol} \% \mathrm{CO}+90 \mathrm{vol} \% \mathrm{H}_{2}$. 


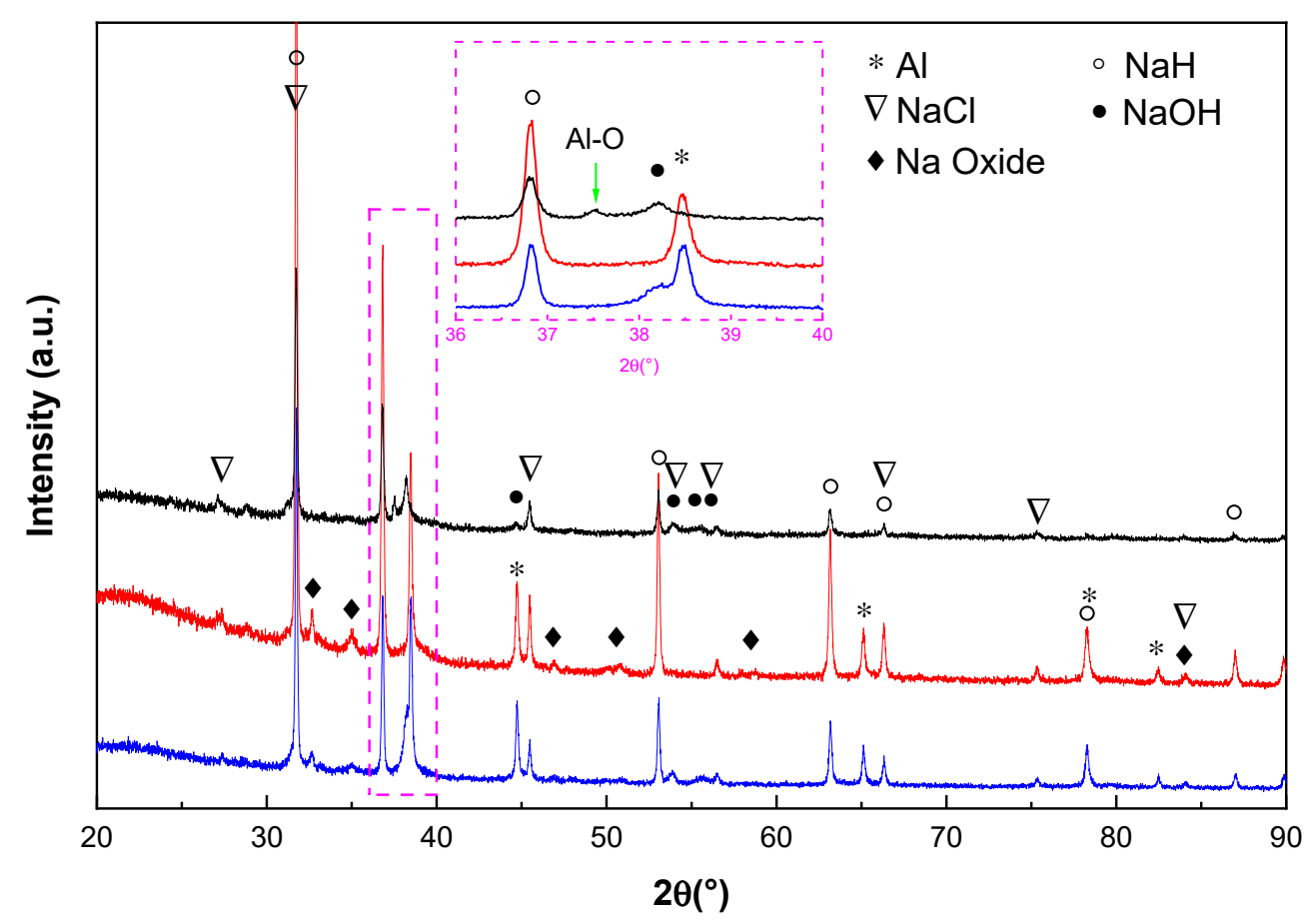

Figure 4. X-ray diffraction patterns of sample after cycling at $170{ }^{\circ} \mathrm{C}$ under 3.0 MPa with different $\mathrm{CO}+\mathrm{H}_{2}$ ratios. - $0.1 \mathrm{vol} \% \mathrm{CO}+99.9 \mathrm{vol} \% \mathrm{H}_{2},-1 \mathrm{vol} \% \mathrm{CO}+99 \mathrm{vol} \% \mathrm{H}_{2},-10 \mathrm{vol} \% \mathrm{CO}+90$ vol $\% \mathrm{H}_{2}$.

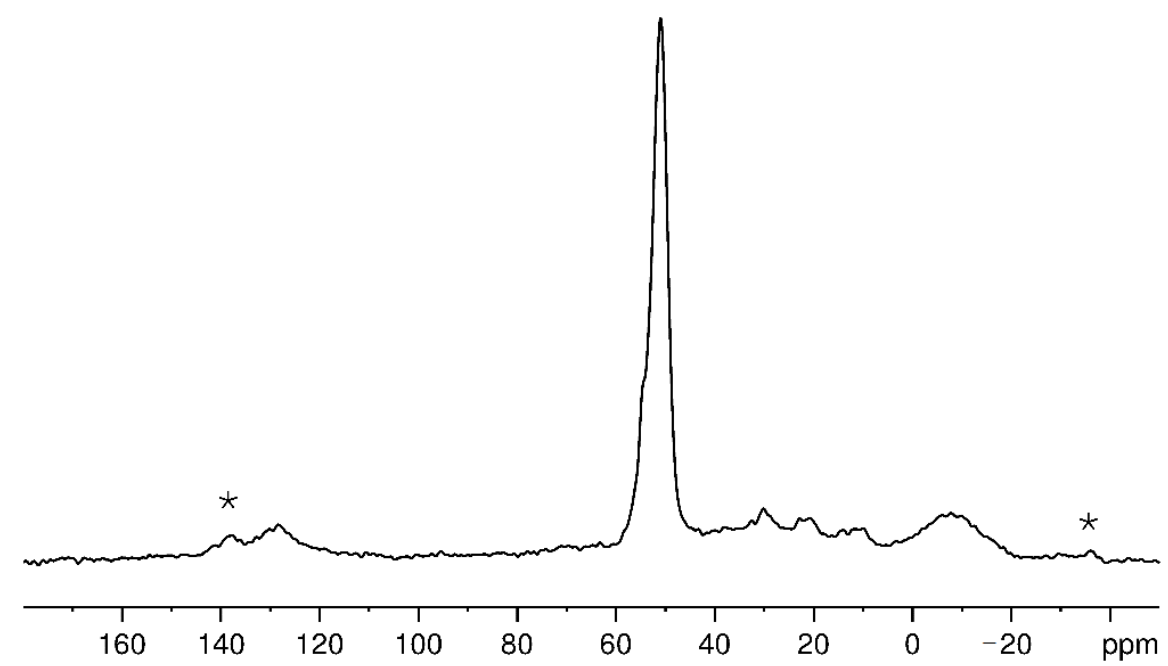

Figure $5 .{ }^{13} \mathrm{C} \mathrm{CP} / \mathrm{MAS}$ NMR spectrum of $10 \mathrm{vol} \% \mathrm{CO}+90 \mathrm{vol} \% \mathrm{H}_{2}$ after the second hydrogenation taken at MAS frequency of $11 \mathrm{kHz}$. Spinning sidebands are marked with stars.

To gain a better understanding of the influences of $\mathrm{CO}$ on the molecular processes during the hydrogenation, the gas-phase FTIR spectra was measured and shown in Figure 6. During the hydrogenation, part of the $\mathrm{CO}\left(v_{\mathrm{C}=\mathrm{O}}=2350 \mathrm{~cm}^{-1}\right)$ reacts with the complex hydride and produces $\mathrm{CH}_{4}\left(v_{\mathrm{C}-\mathrm{H}}=3016 \mathrm{~cm}^{-1}, \delta_{\mathrm{C}-\mathrm{H}}=1305 \mathrm{~cm}^{-1}\right)$. No other gases can be detected in the IR-spectra. 


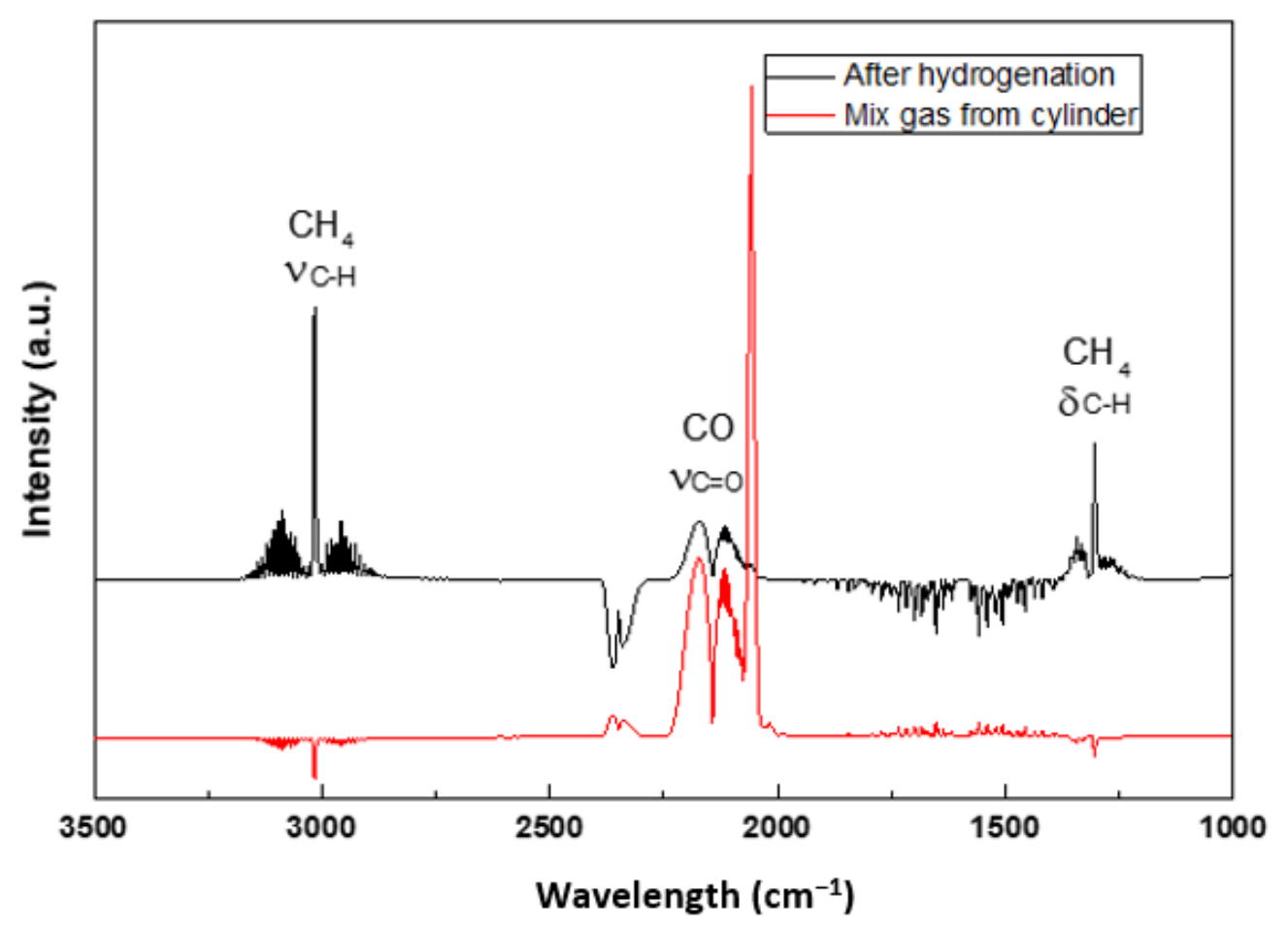

Figure 6. The gas-phase FTIR spectra of products formed during the hydrogenation reaction of the composite material at $170{ }^{\circ} \mathrm{C}$ with $10 \mathrm{vol} \% \mathrm{CO}+90 \mathrm{vol} \% \mathrm{H}_{2}$.

\subsection{The Influence of $\mathrm{CO}_{2}$ Gas on Cycling Behavior of the Complex Hydride Ti-Doped $\mathrm{Na}_{3} \mathrm{AlH}_{6}$}

The hydrogen storage performance with different $\mathrm{CO}_{2}+\mathrm{H}_{2}$ gas ratios were measured and are shown in Figure 7. The influence of $1 \mathrm{vol} \% \mathrm{CO}_{2}$ on the storage capacity is comparable to a mixture with $1 \mathrm{vol} \% \mathrm{CO}$. After 10 cycles, the capacity degradation was $53.5 \%$ in the $1 \mathrm{vol} \% \mathrm{CO}_{2}+99 \mathrm{vol} \% \mathrm{H}_{2}$ gas mixture and $57.3 \%$ in $1 \mathrm{vol} \% \mathrm{CO}+99 \mathrm{vol} \%$ $\mathrm{H}_{2}$. After increasing the concentration of $\mathrm{CO}_{2}$ up to $10 \mathrm{vol} \%$, the capacity degradation becomes larger and reaches $86.8 \%$ after 6 cycles. The performance of hydride with $10 \mathrm{vol}$ $\% \mathrm{CO}_{2}+90 \mathrm{vol} \% \mathrm{H}_{2}$ is better than the one with $10 \mathrm{vol} \% \mathrm{CO}+90 \mathrm{vol} \% \mathrm{H}_{2}$. Several new compounds can be identified by $\mathrm{X}$-ray powder diffractometry after cycling with different $\mathrm{CO}_{2} / \mathrm{H}_{2}$ gas mixtures as shown in Figure 8. The diffraction pattern of dehydrogenated hydride $(\mathrm{Al}, \mathrm{NaH}, \mathrm{NaCl})$ which was cycled in pure hydrogen, was used as a reference. The $\mathrm{Al}, \mathrm{NaH}, \mathrm{NaCl}$ peaks can be found in all these samples. The small amounts of $\mathrm{Na}_{3} \mathrm{AlH}_{6}$ in the composite in $10 \mathrm{vol} \% \mathrm{CO}_{2}+90 \mathrm{vol} \% \mathrm{H}_{2}$ is due to the sluggish kinetics that is getting worse during cycling. The $\mathrm{NaH}$ phase is partly consumed during cycling to produce $\mathrm{Na}$ carbon oxides such as $\mathrm{Na}_{2} \mathrm{CO}_{3}$ and $\mathrm{Na}_{2} \mathrm{C}_{2} \mathrm{O}_{4}$. The ratio of $\mathrm{Al}: \mathrm{NaH}: \mathrm{NaCl}$ becomes smaller that implies that the consumption of $\mathrm{Al}$ and $\mathrm{NaH}$ during cycling with $10 \mathrm{vol} \% \mathrm{CO}_{2}+90$ vol $\% \mathrm{H}_{2}$ gas mixture took place. The loss of $\mathrm{Al}$ and $\mathrm{NaH}$ leads to a reduction of the storage capacity of the material. 


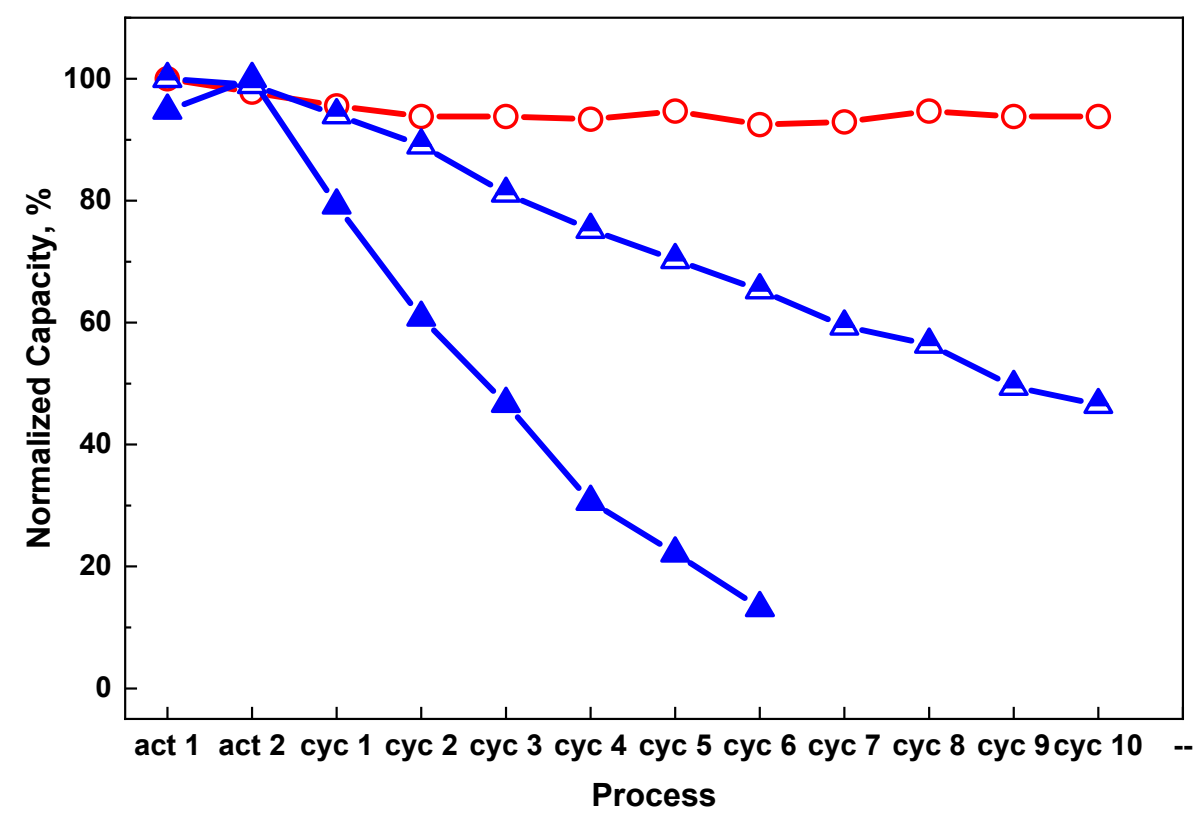

Figure 7. Performance of the composite at $170{ }^{\circ} \mathrm{C}$ under $3.0 \mathrm{MPa}$ with different $\mathrm{CO}_{2}+\mathrm{H}_{2}$ ratios. All samples were hydrogenated and dehydrogenated two times in pure hydrogen (act 1 and act 2)

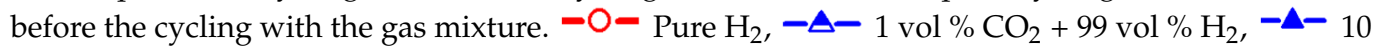
vol \% $\mathrm{CO}_{2}+90$ vol \% $\mathrm{H}_{2}$.

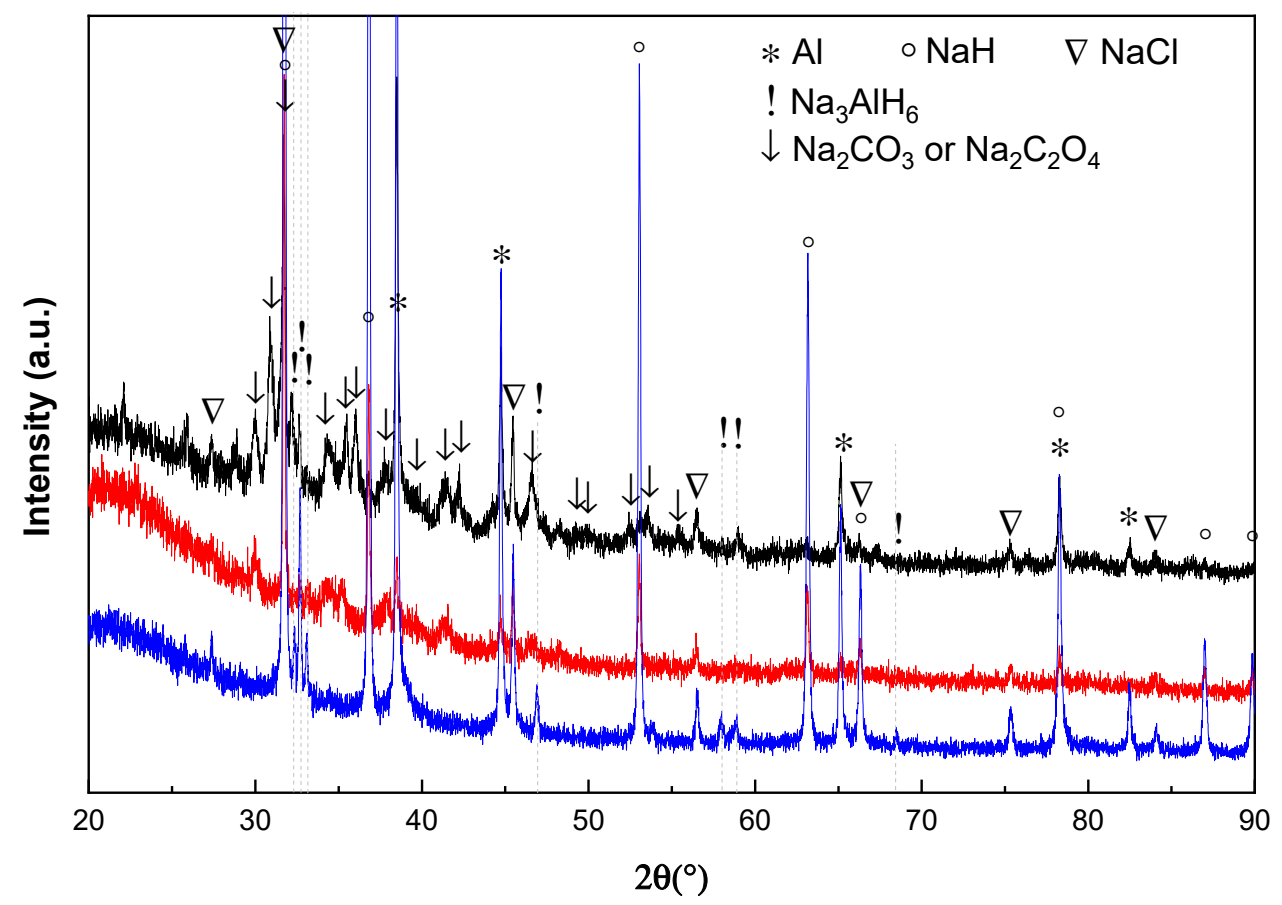

Figure 8. X-ray diffraction patterns of samples after cycling at $170{ }^{\circ} \mathrm{C}$ under 3.0 $\mathrm{MPa}$ with different $\mathrm{CO}_{2}+\mathrm{H}_{2}$ gas ratios. - Pure $\mathrm{H}_{2}$, - 1 vol $\% \mathrm{CO}_{2}+99$ vol $\% \mathrm{H}_{2},-10 \mathrm{vol} \% \mathrm{CO}_{2}+90$ vol \% $\mathrm{H}_{2}$. 


\subsection{Collective Influence of $\mathrm{CO}, \mathrm{CO}_{2}$, and $\mathrm{N}_{2}$ Gas Components on the Cycling Behavior of Ti-Doped Complex Hydride $\mathrm{Na}_{3} \mathrm{AlH}_{6}$}

As mentioned in the introduction, the auto-thermal production of syngas with air contains in addition to $\mathrm{H}_{2}, \mathrm{CO}, \mathrm{CO}_{2}, \mathrm{H}_{2} \mathrm{O}$ also high amounts of $\mathrm{N}_{2}$ gas. The high amount of neutral $\mathrm{N}_{2}$ reduces the partial pressure of $\mathrm{H}_{2}$ in the gas mixtures and changes the hydrogenation behavior of the complex hydride. Our experiments with $62 \mathrm{vol} \% \mathrm{~N}_{2}+38$ vol $\% \mathrm{H}_{2}$ gas mixture shows that 3.0 MPa total pressure which corresponds to only 1.1 MPa of hydrogen partial pressure is not high enough to recharge the sample at $170^{\circ} \mathrm{C}$, see Figure 9. This pressure of $1.1 \mathrm{MPa}$ is below the equilibrium pressure at $170^{\circ} \mathrm{C}$, which is equal to $1.5 \mathrm{MPa}$. In order to reach partial $\mathrm{H}_{2}$ pressure of $3 \mathrm{MPa}$ in a gas mixture of 1.5 $\mathrm{vol} \% \mathrm{CO}+10 \mathrm{vol} \% \mathrm{CO}_{2}+27 \mathrm{vol} \% \mathrm{H}_{2}+61.5 \mathrm{vol} \% \mathrm{~N}_{2}$, the overall gas pressure must be increased to $11 \mathrm{MPa}$. As shown in Figure 8, the degradation reaches $94 \%$ after 6 cycles with this gas mixture. The fast degradation process seems to be due to combined influence of the different gas impurities during cycling. Each kind of gas impurity affects the complex hydride in a different way. Figure 10 shows the $\mathrm{X}$-ray diffraction pattern of the complex hydride after 6 cycles with the $1.5 \mathrm{vol} \% \mathrm{CO}+10 \mathrm{vol} \% \mathrm{CO}_{2}+27 \mathrm{vol} \% \mathrm{H}_{2}+61.5 \mathrm{vol}$ $\% \mathrm{~N}_{2}$ gas mixture, and for comparison, the pattern of the decomposed complex hydride after cycling in pure $\mathrm{H}_{2}$ as a reference. Only very small diffraction peaks of $\mathrm{Na}_{3} \mathrm{AlH}_{6}$ are observed after the cycling and decomposition. The main reflections belong to Al-metal, $\mathrm{NaH}$, and $\mathrm{NaCl}$ from the doping process. No or very small reflections of Al-metal and $\mathrm{NaH}$ or $\mathrm{Na}_{3} \mathrm{AlH}_{6}$ can be observed in the diffraction pattern after only 6 cycles. $\mathrm{Na}_{2} \mathrm{CO}_{3}$ can be detected as newly formed compound, which can easily be explained by a reaction of $\mathrm{NaO}(\mathrm{H})$ with $\mathrm{CO}_{2}$. No additional Al-O-compounds are detected.

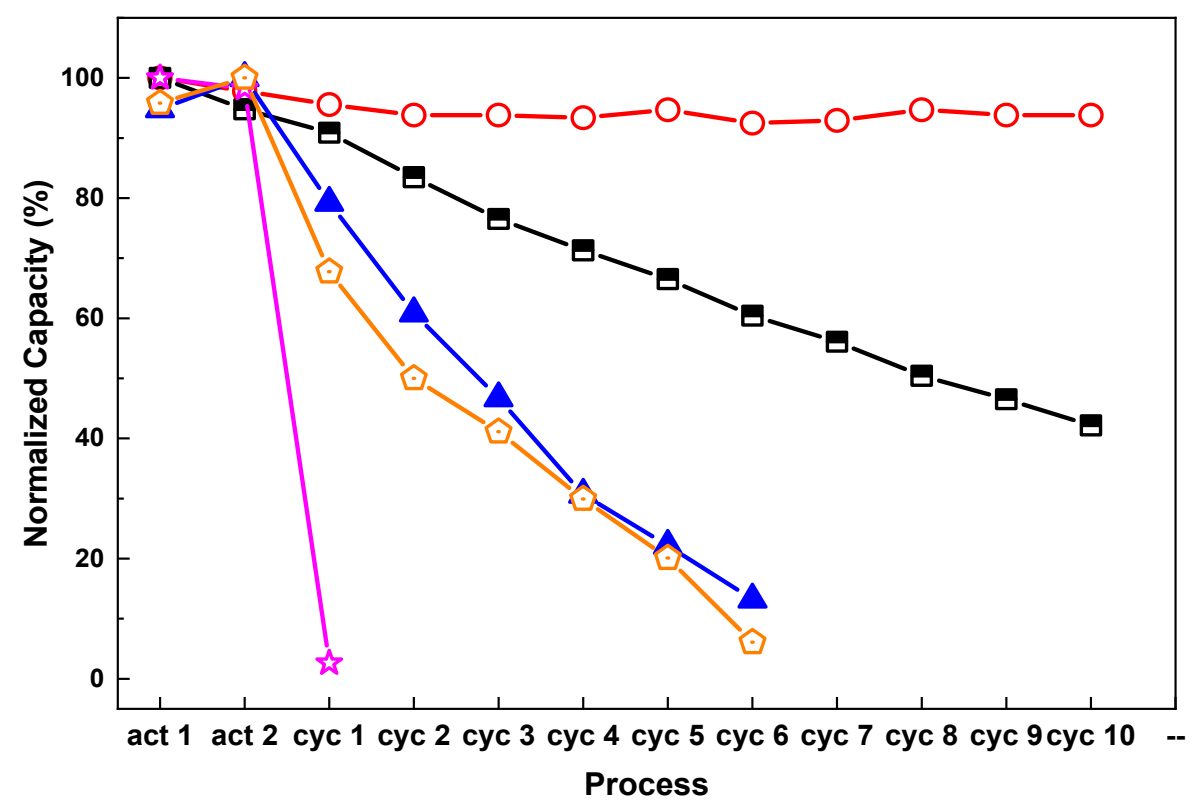

Figure 9. Cyclic performance of the composite at $170{ }^{\circ} \mathrm{C}$ under $11 \mathrm{MPa}$ hydrogenation in $1.5 \mathrm{vol} \%$ $\mathrm{CO}+10 \mathrm{vol} \% \mathrm{CO}_{2}+27 \mathrm{vol} \% \mathrm{H}_{2}+61.5 \mathrm{vol} \% \mathrm{~N}_{2}$ - - - gas mixture in comparison to cycling with pure $\mathrm{H}_{2}-\mathrm{O}-$, with 1 vol $\% \mathrm{CO}+99$ vol $\% \mathrm{H}_{2}-\boldsymbol{-}-$, with $10 \mathrm{vol} \% \mathrm{CO}_{2}+90$ vol $\% \mathrm{H}_{2}-\boldsymbol{\Delta}-$ and with $62 \mathrm{vol} \% \mathrm{~N}_{2}+38 \mathrm{vol} \% \mathrm{H}_{2}$ 一安- at $3 \mathrm{MPa}$ total pressure hydrogenation. 


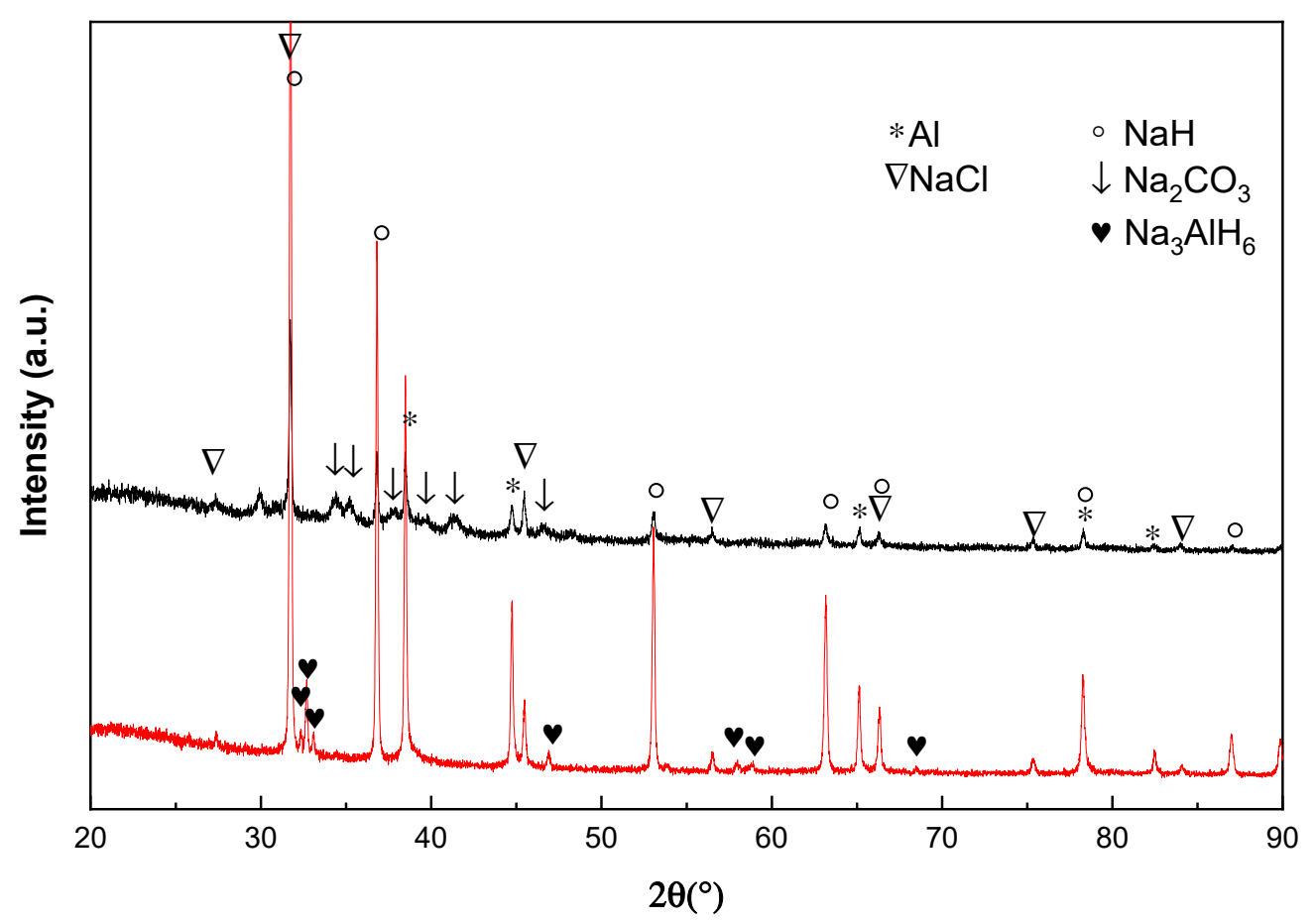

Figure 10. X-ray diffraction patterns of decomposed Ti-doped $\mathrm{Na}_{3} \mathrm{AlH}_{6}$ after cycling at $170{ }^{\circ} \mathrm{C}$ under $11 \mathrm{MPa}$ hydrogenation with - $1.5 \mathrm{vol} \% \mathrm{CO}+10 \mathrm{vol} \% \mathrm{CO}_{2}+27 \mathrm{vol} \% \mathrm{H}_{2}+61.5 \mathrm{vol} \% \mathrm{~N}_{2}$ gas mixture and under $3 \mathrm{MPa}$ hydrogenation with - pure $\mathrm{H}_{2}$.

\section{Discussions}

In this paper, we reported about the cycling performance of Ti-doped $\mathrm{Na}_{3} \mathrm{AlH}_{6}+\mathrm{Al}+$ activated carbon composite in pure hydrogen and studied the influence of different ratios of $\mathrm{CO}, \mathrm{CO}_{2}, \mathrm{~N}_{2}$ gas components on the hydrogen storage properties of this complex hydride. By addition of activated carbon and aluminum to $\mathrm{TiCl}_{3}$-activated $\mathrm{Na}_{3} \mathrm{AlH}_{6}$, the cycling stability and hydrogen storage capacity could be successfully enhanced in comparison to undoped material in pure hydrogen. Both $\mathrm{CO}, \mathrm{CO}_{2}$ gas components react with the hydride mixture and cause a serious decline in hydrogen storage capacity to form Al-O- and/or carboxyl compounds and $\mathrm{Na}-\mathrm{O}-$ and/or carbonates, and $\mathrm{CH}_{4}$.

Several reaction pathways exist, which can explain the conversion of $\mathrm{CO} / \mathrm{CO}_{2}$ to methane and water.

- reduction of $\mathrm{CO} / \mathrm{CO}_{2}$ with $\mathrm{Na}_{3} \mathrm{AlH}_{6}$.

- reduction of $\mathrm{CO} / \mathrm{CO}_{2}$ with $\mathrm{NaH}$.

- reduction of $\mathrm{CO} / \mathrm{CO}_{2}$ with $\mathrm{H}_{2}$ under the influence of $\mathrm{TiAl}_{\mathrm{x}}$ as catalyst.

Hugelshofer et al. [11] described the reaction of $\mathrm{LiAlH}_{4}$ with $\mathrm{CO}_{2}$ and postulated the formation of various amorphous metal oxides, which cannot be identified by XRD. The similar reactivity of the complex aluminum hydrides $\mathrm{LiAlH}_{4}$ and $\mathrm{Na}_{3} \mathrm{AlH}_{6}$ could explain the formation of some amorphous metal oxides compounds with the general formula $\mathrm{Na}_{\mathrm{x}} \mathrm{Al}_{\mathrm{Y}} \mathrm{O}_{\mathrm{z}}$. The structure and the amount of formed oxide-compounds strongly depends on the amount of $\mathrm{CO}$ or $\mathrm{CO}_{2}$ in the gas mixture, while $\mathrm{CH}_{4}$ and $\mathrm{H}_{2} \mathrm{O}$ are produced. Water seems to be the main reason for the production of metal oxide compounds and subsequently, reduced reversibility of the storage material.

The reduction of $\mathrm{CO}_{2}$ to methane in the presence of mechanochemically activated alkali metal hydrides were discovered by Zhao et al. [23]. They observed elemental carbon, hydrogen, alkali metal oxides, and carbonates as final products from the reaction of the oxides with $\mathrm{CO}_{2}$. Similar reaction pathways can be expected in our case with the exception that in the presence of $\mathrm{TiAl}_{\mathrm{x}}$-catalyst hydrogenated gaseous compounds $\left(\mathrm{CH}_{4}\right)$ can be observed. 
The in situ formed Al-Ti active species [30], which are acting as a catalyst for the hydrogenation of $\mathrm{NaH} / \mathrm{Al}$ to $\mathrm{Na}_{3} \mathrm{AlH}_{6}$, can also act as catalyst in a hydrogen atmosphere for the reduction of $\mathrm{CO}$ to produce $\mathrm{CH}_{4}$ [11].

In comparison to these three examples, our system is more complicated, since all three different reaction pathways can take place at the same time. During these reduction processes, stoichiometric amounts of $\mathrm{H}_{2} \mathrm{O}$ are produced which consequently react with hydride species to produce $\mathrm{Na}$ - and/or Al-oxide compounds. In a following process, these oxide compounds can react with $\mathrm{CO}_{2}$ producing carbonates and in case of $\mathrm{CO}$ producing formic acid compounds. A loss of catalytic activity of Al-Ti species and the oxidation of Naand Al-hydride species lower the reversibility of the composite system and hence degrade the hydrogen storage capacity.

\section{Conclusions}

Ti-doped $\mathrm{Na}_{3} \mathrm{AlH}_{6}$ is a medium temperature hydrogen storage material with a theoretical hydrogen storage capacity of $3 \mathrm{wt} \% \mathrm{H}_{2}$ and an impressive stable capacity over several hundreds of de- and re-hydrogenation cycles in pure hydrogen. Nowadays, most of the worldwide used hydrogen is produced from natural gas. This means that significant amounts of $\mathrm{CO}$ and $\mathrm{CO}_{2}$ could be present in the produced hydrogen gas. Therefore, we have tested the reactivity of $\mathrm{CO}$ and $\mathrm{CO}_{2}$ against Ti-doped $\mathrm{N}_{3} \mathrm{AlH}_{6}$. Both gases, $\mathrm{CO}$ and $\mathrm{CO}_{2}$, show a high affinity to the complex hydrides and just after few hydrogenation/dehydrogenation cycles, cause irreversible damage. The complex hydride could not be regenerated with pure hydrogen under current experimental conditions. The $\mathrm{N}_{2}$ gas impurity does not react with the hydride, but it greatly reduces the partial pressure of $\mathrm{H}_{2}$ and therefore cause difficulties for the hydrogenation reaction. The experimental data show that syngas cannot be used for the recharging of these complex hydrides, therefore prior to the hydrogenation process, a thorough purification of hydrogen from $\mathrm{CO}, \mathrm{CO}_{2}$, and of $\mathrm{N}_{2}$ is necessary. This purification process can be realized using well-known separation methods such as PSA (pressure swing adsorption), membrane techniques (Pd-based membranes, ceramic membranes, electrochemical membranes), and cryogenic separation. On the other hand, due to the high reactivity of Ti-doped $\mathrm{Na}_{3} \mathrm{AlH}_{6}$ towards $\mathrm{CO}$ and $\mathrm{CO}_{2}$, the material can be used for the absorption of small amounts of these gases and the production of high purity hydrogen for PEM-fuel cell applications.

Author Contributions: Conceptualization, R.U., K.P. and M.F.; formal analysis, T.S., R.U. and K.P.; investigation, T.S. and K.P.; writing — original draft preparation, T.S.; writing - review and editing, K.P., R.U. and M.F.; visualization, T.S., R.U. and K.P.; supervision, M.F.; funding acquisition, T.S. and M.F. All authors have read and agreed to the published version of the manuscript.

Funding: The research was financially supported by MOST Scientific Project (2018YFE0100700), Guangdong Scientific Project (No. 2017B030314081) and the GDAS Project of Science and Technology Development (No. 2017GDASCX-0506, 2019GDASYL-0503005) in China as well as EFRE NRW project funding Nr. EFRE-0800055. The basic financial support of the Max-Planck-Institut für Kohlenforschung is greatly appreciated.

Acknowledgments: The authors acknowledged the support of B. Zibrowius for the measurement of solid state NMR-spectra.

Conflicts of Interest: The authors declare no conflict of interest.

\section{References}

1. Edwards, P.P.; Kuznetsov, V.L.; David, W.I.F. Hydrogen energy. Philos. Trans. R. Soc. A 2007, 365, 1043-1056. [CrossRef] [PubMed]

2. Züttel, A. Hydrogen storage methods. Naturwissenschaften 2004, 91, 157-172. [CrossRef] [PubMed]

3. Urbanczyk, R.; Peinecke, K.; Meggouh, M.; Minne, P.; Peil, S.; Bathen, D.; Felderhoff, M. Design and operation of an aluminium alloy tank using doped Na 3 AlH 6 in kg scale for hydrogen storage. J. Power Sources 2016, 324, 589-597. [CrossRef]

4. Farzad, S.; Mandegari, M.A.; Görgens, J.F. A critical review on biomass gasification, co-gasification, and their environmental assessments. Biofuel Res. J. 2016, 3, 483-495. [CrossRef] 
5. Marcantonio, V.; Ferrario, A.M.; Di Carlo, A.; Del Zotto, L.; Monarca, D.; Bocci, E. Biomass Steam Gasification: A Comparison of Syngas Composition between a 1-D MATLAB Kinetic Model and a 0-D Aspen Plus Quasi-Equilibrium Model. Computation 2020, 8, 86. [CrossRef]

6. Klein, H. Hydrogen and Carbon Monoxide: Synthesis Gases. In Industrial Gases Processing; Häring, H.W., Ed.; WILEY-VCH Verlag GmbH \& Co. KGaA: Weinheim, Germany, 2008; pp. 145-149.

7. Rostrup-Nielsen, J. Reforming and Gasification-Fossil Energy Carriers. In Hydrogen and Fuel Cells; Stolten, D., Ed.; WILEY-VCH Verlag GmbH \& Co. KGaA: Weinheim, Germany, 2010; pp. 291-305.

8. Ahmed, S. Hydrogen from hydrocarbon fuels for fuel cells. Int. J. Hydrog. Energy 2001, 26, 291-301. [CrossRef]

9. Rampe, T. Entwicklung eines Bioethanol-Dampfreformers zur Erzeugung von Wasserstoff für den Einsatz in einem PEMBrennstoffzellen-BHKW. Ph.D. Thesis, Universität Duisburg-Essen, Duisburg, Germany, 2004.

10. Dedrick, D.E.; Behrens, R., Jr.; Bradshaw, R.W. The Reactivity of Sodium Alanates with $\mathrm{O}_{2}, \mathrm{H}_{2} \mathrm{O}$, and $\mathrm{CO}_{2}$, An Investigation of Complex Metal Hydride Contamination in the Context of Automotive Systems; Sandia Report, SAND2007-4960; Sandia National Laboratories: Washington, DC, USA, 2007.

11. Hugelshofer, C.L.; Borgschulte, A.; Callini, E.; Matam, S.K.; Gehrig, J.C.; Hog, D.T.; Züttel, A. Gas-Solid Reaction of Carbon Dioxide with Alanates. J. Phys. Chem. C 2014, 118, 15940-15945. [CrossRef]

12. Sandrock, G.D.; Goodell, P.D. Surface poisoning of LaNi5, FeTi and (Fe,Mn)Ti by $\mathrm{O}_{2}$, Co and H $\mathrm{H}_{2}$ O. J. Less Common Met. 1980, 73, 161-168. [CrossRef]

13. Han, J.I.; Lee, J.-Y. The effect of CO impurity on the hydrogenation properties of LaNi5, LaNi4.7Al0.3 and MmNi4.5Al0.5 during hydriding-dehydriding cycling. J. Less Common Met. 1989, 152, 319-327. [CrossRef]

14. Sandrock, G.; Goodell, P. Cyclic life of metal hydrides with impure hydrogen: Overview and engineering considerations. J. Less Common Met. 1984, 104, 159-173. [CrossRef]

15. Ono, S.; Ishido, Y.; Akiba, E.; Jindo, K.; Sawada, Y.; Kitagawa, I.; Kakutani, T. The effect of $\mathrm{CO}_{2}, \mathrm{CH}_{4}, \mathrm{H}_{2} \mathrm{O}$ and $\mathrm{N}_{2}$ on $\mathrm{Mg}-\mathrm{Ni}$ alloys as hydrogen transporting media. Int. J. Hydrog. Energy 1986, 11, 381-387. [CrossRef]

16. Varin, R.; Zbroniec, L. Decomposition behavior of unmilled and ball milled lithium alanate $\left(\mathrm{LiAlH}_{4}\right)$ including long-term storage and moisture effects. J. Alloy Compd. 2010, 504, 89-101. [CrossRef]

17. Dunikov, D.; Borzenko, V.; Malyshenko, S. Influence of impurities on hydrogen absorption in a metal hydride reactor. Int. J. Hydrog. Energy 2012, 37, 13843-13848. [CrossRef]

18. Tai, Y.-L.; Wang, L.; Chen, H.-Q.; Dong, B.-X.; Kan, X.-T.; Teng, Y.-L. Improved mechanochemical methanation performance of the metal carbonate-hydride system. Solid State Sci. 2020, 109, 106398. [CrossRef]

19. Gamba, N.S.; Puszkiel, J.; Larochette, P.A.; Gennari, F.C. Dual application of Ti-catalyzed Li-RHC composite for H2 purification and CO methanation. Int. J. Hydrog. Energy 2020, 45, 19493-19504. [CrossRef]

20. Grasso, M.L.; Puszkiel, J.; Gennari, F.C.; Santoru, A.; Dornheim, M.; Pistidda, C. CO2 reactivity with $\mathrm{Mg}_{2} \mathrm{NiH}_{4}$ synthesized by in situ monitoring of mechanical milling. Phys. Chem. Chem. Phys. 2020, 22, 1944-1952. [CrossRef]

21. Zhao, J.; Wei, Y.-F.; Cai, Y.-L.; Wang, L.-Z.; Xie, J.; Teng, Y.-L.; Zhu, W.; Shen, M.; Dong, B.-X. Highly Selective and Efficient Reduction of $\mathrm{CO}_{2}$ to Methane by Activated Alkaline Earth Metal Hydrides without a Catalyst. ACS Sustain. Chem. Eng. 2019, 7, 4831-4841. [CrossRef]

22. Grasso, M.L.; Puszkiel, J.; Albanesi, L.F.; Dornheim, M.; Pistidda, C.; Gennari, F.C. $\mathrm{CO}_{2}$ reutilization for methane production via a catalytic process promoted by hydrides. Phys. Chem. Chem. Phys. 2019, 21, 19825-19834. [CrossRef]

23. Zhao, J.; Dong, B.-X.; Teng, Y.-L.; Wang, L.; Ping, C.; Li, Z.-W. Dehydrogenation reactions of mechanically activated alkali metal hydrides with CO2 at room temperature. Int. J. Hydrog. Energy 2018, 43, 5068-5076. [CrossRef]

24. Dong, B.-X.; Zhao, J.; Wang, L.-Z.; Teng, Y.-L.; Liu, W.-L.; Wang, L. Mechanochemical synthesis of COx-free hydrogen and methane fuel mixtures at room temperature from light metal hydrides and carbon dioxide. Appl. Energy 2017, 204, 741-748. [CrossRef]

25. Peinecke, K.; Meggouh, M.; Felderhoff, M. Mechanochemical synthesis and effect of various additives on the hydrogen absorptiondesorption behavior of Na3AlH6. J. Mater. Sci. 2018, 53, 13742-13750. [CrossRef]

26. Urbanczyk, R.; Peinecke, K.; Felderhoff, M.; Hauschild, K.; Kersten, W.; Peil, S.; Bathen, D. Aluminium alloy based hydrogen storage tank operated with sodium aluminium hexahydride Na3AlH6. Int. J. Hydrog. Energy 2014, 39, 17118-17128. [CrossRef]

27. Adelhelm, P.; De Jongh, P.E. The impact of carbon materials on the hydrogen storage properties of light metal hydrides. J. Mater. Chem. 2010, 21, 2417-2427. [CrossRef]

28. Wang, W.; Buchholz, A.; Arnold, A.; Xu, M.; Hunger, M. Effect of surface methoxy groups on the 27Al quadrupole parameters of framework aluminum atoms in calcined zeolite H-Y. Chem. Phys. Lett. 2003, 370, 88-93. [CrossRef]

29. Slaughter, J.; Peel, A.J.; Wheatley, A.E.H. Reactions of Trimethylaluminium: Modelling the Chemical Degradation of Syn-thetic Lubricants. Chem. Eur. J. 2017, 23, 167-175. [CrossRef]

30. Singh, S.; Eijt, S.; Huot, J.; Kockelmann, W.; Wagemaker, M.; Mulder, F. The $\mathrm{TiCl}_{3}$ catalyst in NaAlH4 for hydrogen storage induces grain refinement and impacts on hydrogen vacancy formation. Acta Mater. 2007, 55, 5549-5557. [CrossRef] 